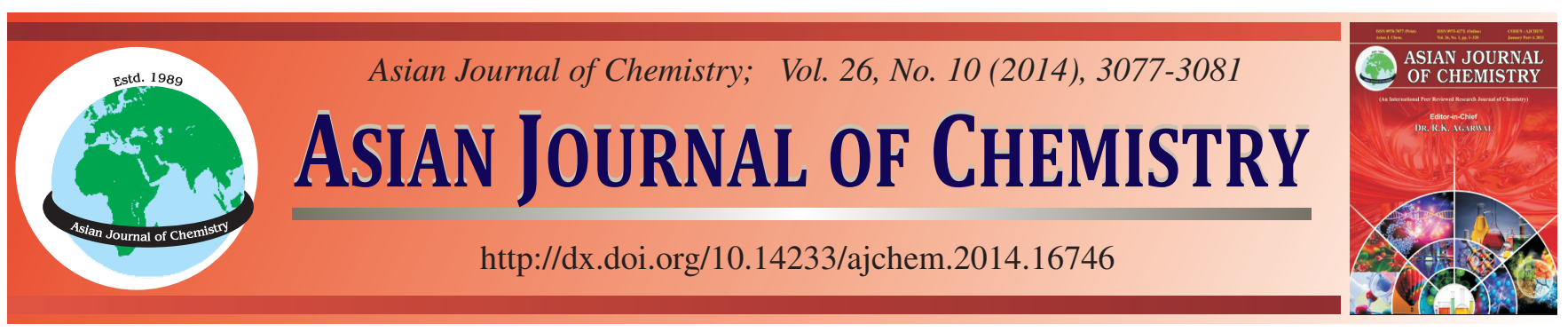

\title{
Synthesis, Characterization and X-ray Crystal Structure of 2',3'-Dideoxy-6'-fluorocarbocyclic Nucleoside Analogue
}

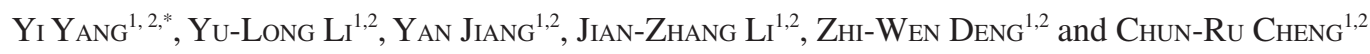

${ }^{1}$ School of Chemistry and Pharmaceutical Engineering, Sichuan University of Science and Engineering, Zigong 643000, P.R. China ${ }^{2}$ Key Laboratory of Green Catalysis of Higher Education Institutes of Sichuan, Sichuan University of Science \& Engineering, Zigong 643000, P.R. China

*Corresponding author: Fax: +86 813 5505606; Tel: +86 813 5505601; E-mail: yangyiyoung@ 163.com

Received: 23 November 2013;

Accepted: 2 Janaury 2014;

Published online: 10 May 2014;

AJC-15184

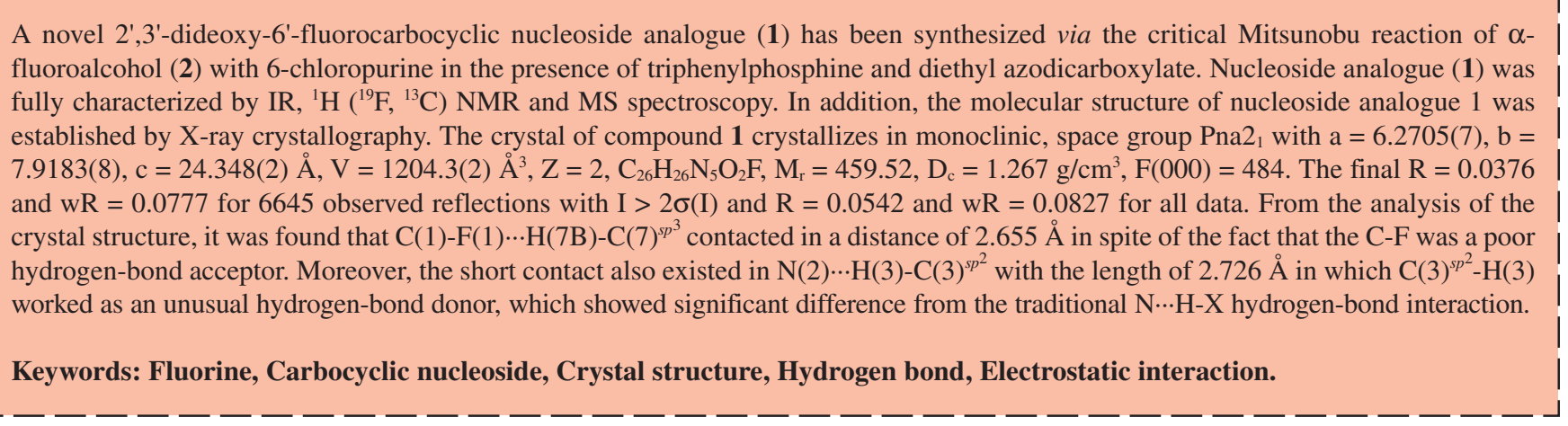

\section{INTRODUCTION}

Organofluorine compounds have found widespread applications in medicinal chemistry, bioorganic chemistry and pharmaceutical industries since the discovery of the early synthetic antineoplastic agent 5 -fluorouracil ${ }^{1-7}$. Now over 150 fluorinated drugs have come to the market and make up 20$25 \%$ of all the drugs in the pharmaceutical pipeline ${ }^{2}$. The incorporation of fluorine atom into a drug allows simultaneous modulation of metabolic stability, bioavailability and proteinligand interactions due to its small size, high electronegativity and low polarizability ${ }^{1,3}$. Despite the great progress and success in fluorine substitution for drugs hunting, the understanding of the relationship between the structures of fluorinated compounds and bioactivities is still very empirical and not clear enough ${ }^{8}$. In particular, how to interpret the fluorine effects on protein-ligand binding affinity and selectivity at the molecular level confronts considerable challenges ${ }^{8}$. It is evident that structural information is critical for elucidating the contributions of fluorine to bioactivity potency ${ }^{6-8}$. Considering our continuing conformational studies for potentially bioactive fluorinated nucleoside analogues ${ }^{9-10}$, herein we report the $\mathrm{X}$ ray structure of a novel 2',3'-dideoxy-6'-fluorocarbocyclic nucleoside analogue $\mathbf{1}$ and take systematic analysis of the crystal data in order to obtain a deeper understanding of the fluorine influences on the conformation of carbocyclic nucleoside.

\section{EXPERIMENTAL}

All reactions were carried out using standard Schlenk and vacuum-line techniques under $\mathrm{N}_{2}$ atmosphere. Solvent THF was distilled from sodium and benzophenone. Triphenylphosphine $\left(\mathrm{Ph}_{3} \mathrm{P}\right)$ and diethyl azodicarboxylate (DEAD) was commercially available and used as received. IR spectra were recorded at room temperature on a Bruker Vector 22 infrared spectrophotometer. ${ }^{1} \mathrm{H}$ NMR was recorded on a Bruker AM300 spectrometer. ${ }^{19} \mathrm{~F}$ NMR was recorded on a Bruker AM300 spectrometer $\left(\mathrm{FCCl}_{3}\right.$ as outside standard and low field is positive). ${ }^{13} \mathrm{C}$ NMR was recorded on a Bruker AM-400 spectrometer. Chemical shifts $(\delta)$ are reported in parts per million and coupling constants $(J)$ are in hertz. Optical rotations were measured using a PerkineElmer 241 polarimeter. Crystallographic data were analyzed with Rigaku FCR Diffractimer. Melting points were determined on a SGW X-4 microscopic melting point apparatus and were uncorrected. 


\section{Synthetic procedure}

Step-1: To a mixture of $\alpha$-fluoroalcohol $(2)^{10}(0.069 \mathrm{~g}$, $0.204 \mathrm{mmol}), 6$-chloropurine $(0.064 \mathrm{~g}, 0.416 \mathrm{mmol})$ and $\mathrm{PPh}_{3}$ $(0.142 \mathrm{~g}, 0.541 \mathrm{mmol})$ in dry THF $(2 \mathrm{~mL})$ was added diethyl azodicarboxylate $(0.095 \mathrm{~g}, 0.546 \mathrm{mmol})$ slowly at $0{ }^{\circ} \mathrm{C}$. Then the reaction mixture was warmed to room temperature and stirred overnight. The solvent was removed in vacuo and the residue was purified by flash chromatography (petroleum ether/ethyl acetate $=3: 1$ ) on silica gel to give compound $\mathbf{3}$ as a pale yellow oil $(0.047 \mathrm{~g}, 48 \%$ yield $) .[\alpha]^{25}{ }_{\mathrm{D}}=-42.4^{\circ}(\mathrm{c} 0.75$, $\mathrm{CHCl}_{3}$ ); IR (KBr, $\left.v_{\max }, \mathrm{cm}^{-1}\right)$ : 3064, 2864, 1776, 1699, 1591, $1561,1402,1336,1200,1102 ;{ }^{1} \mathrm{H}$ NMR $\left(300 \mathrm{MHz}, \mathrm{CDCl}_{3}\right.$, TMS) $\delta$ ppm: $8.79(\mathrm{~s}, 1 \mathrm{H}), 8.05(\mathrm{~d}, J=2.4 \mathrm{~Hz}, 1 \mathrm{H}), 7.40-7.31$ $(\mathrm{m}, 10 \mathrm{H}), 6.22(\mathrm{~d}, J=5.7 \mathrm{~Hz}, 1 \mathrm{H}), 6.02(\mathrm{~d}, J=17.7 \mathrm{~Hz}, 1 \mathrm{H})$, $5.95(\mathrm{~d}, J=5.7 \mathrm{~Hz}, 1 \mathrm{H}), 5.07$ (dd, $J=52.8 \mathrm{~Hz}, 5.4 \mathrm{~Hz}, 1 \mathrm{H})$, $4.78-4.54$ (m, 4H), 3.91 (dd, $J=9.6 \mathrm{~Hz}, 4.5 \mathrm{~Hz}, 1 \mathrm{H}), 3.69$ $3.58(\mathrm{~m}, 2 \mathrm{H}), 3.40(\mathrm{~d}, J=27.3 \mathrm{~Hz}, 1 \mathrm{H}) ;{ }^{13} \mathrm{C}$ NMR $(100.7$ $\left.\mathrm{MHz}, \mathrm{CDCl}_{3}\right) \delta$ ppm: 152.1, 151.9, 150.9, 144.9, 137.7, 137.6, $135.2,131.5,128.7,128.6,128.3,128.2,128.0,127.8,93.3$ $(\mathrm{d}, J=190.5 \mathrm{~Hz}), 73.7,72.4,70.2,60.8(\mathrm{~d}, J=16.9 \mathrm{~Hz}), 54.6$ $(\mathrm{d}, J=21.9 \mathrm{~Hz}) ;{ }^{19} \mathrm{~F}$ NMR $\left(282 \mathrm{MHz}, \mathrm{CDCl}_{3}\right) \delta \mathrm{ppm}:-188.3$ (ddd, $J=44.0 \mathrm{~Hz}, 25.4 \mathrm{~Hz}, 18.0 \mathrm{~Hz}, 1 \mathrm{~F}$ ); MS (ESI) $\mathrm{m} / z, 479$ $(\mathrm{M}+\mathrm{H})^{+}, 501(\mathrm{M}+\mathrm{Na})^{+}$; HRMS Calcd for $\mathrm{C}_{26} \mathrm{H}_{25} \mathrm{~N}_{4} \mathrm{O}_{2} \mathrm{FCl}$ : 479.1650; Found: 479.1645 .

Step-2: Compound 3 (0.050 g, $0.105 \mathrm{mmol})$ was dissolved in $\mathrm{NH}_{3} / \mathrm{MeOH}(2 \mathrm{~mL})$ in a sealed tube. The mixture was heated to $80^{\circ} \mathrm{C}$ and stirred for $12 \mathrm{~h}$. The solvent was then removed in vacuo and the residue was purified by flash chromatography $\left(\mathrm{CH}_{2} \mathrm{Cl}_{2} / \mathrm{MeOH}=20: 1\right)$ on silica gel to give compound $\mathbf{1}$ as a white solid $(0.041 \mathrm{~g}, 86 \%$ yield $)$. m.p.: $193{ }^{\circ} \mathrm{C} ;[\alpha]^{25}{ }_{\mathrm{D}}=$ $-25.5^{\circ}\left(\mathrm{c} 1.60, \mathrm{CHCl}_{3}\right)$; IR $\left(\mathrm{KBr}, v_{\max }, \mathrm{cm}^{-1}\right): 3311,2922,2851$, 1647, 1597, 1473, 1096, 698; ${ }^{1} \mathrm{H}$ NMR $\left(300 \mathrm{MHz}, \mathrm{CDCl}_{3}\right.$, TMS) $\delta$ ppm: 8.39 (s, 1H), $7.74(\mathrm{~s}, 1 \mathrm{H}), 7.39-7.35(\mathrm{~m}, 10 \mathrm{H})$, $6.19(\mathrm{~d}, J=5.1 \mathrm{~Hz}, 1 \mathrm{H}), 5.97-5.92(\mathrm{~m}, 2 \mathrm{H}), 5.78$ (s, 2H), 5.07 (dd, $J=54.0 \mathrm{~Hz}, 5.7 \mathrm{~Hz}, 1 \mathrm{H}), 4.76-4.52$ (m, 4H), 3.85 (dd, $J=10.2 \mathrm{~Hz}, 5.1 \mathrm{~Hz}, 1 \mathrm{H}), 3.67-3.59$ (m, 2H), 3.36 (d, $J=24.0$ $\mathrm{Hz}, 1 \mathrm{H}) ;{ }^{13} \mathrm{C} \mathrm{NMR}\left(100.7 \mathrm{MHz}, \mathrm{CDCl}_{3}\right) \delta \mathrm{ppm}: 155.4,153.0$, $140.2(\mathrm{~d}, J=5.8 \mathrm{~Hz}), 137.7,137.7,134.7,128.7,128.6,128.5$, 128.3, 128.0, 127.9, 127.8, $93.2(\mathrm{~d}, J=190.2 \mathrm{~Hz}), 73.6,72.5$, $70.4,60.0(\mathrm{~d}, J=15.8 \mathrm{~Hz}), 54.4(\mathrm{~d}, J=22.4 \mathrm{~Hz}), 41.0 ;{ }^{19} \mathrm{~F}$ NMR $\left(282 \mathrm{MHz}, \mathrm{CDCl}_{3}\right) \delta$ ppm: -190.0 (ddd, $J=44.0 \mathrm{~Hz}$, $25.4 \mathrm{~Hz}, 18.0 \mathrm{~Hz}, 1 \mathrm{~F})$; MS (ESI) $m / z, 460(\mathrm{M}+\mathrm{H})^{+}, 482(\mathrm{M}+$ $\mathrm{Na})^{+}$; HRMS Calcd for $\mathrm{C}_{26} \mathrm{H}_{27} \mathrm{~N}_{5} \mathrm{O}_{2} \mathrm{~F}$ : 460.2149; Found: 460.2143 .

Determination of crystal structure: A white single crystal of 2',3'-dideoxy-6'-fluorocarbocyclic nucleoside (1) for X-ray diffraction analysis was grown by the slow evaporation of methanol solutions at room temperature. The crystal of compound 1 with dimensions of $0.369 \times 0.311 \times 0.079 \mathrm{~mm}$ was mounted on a Rigaku RAXIS-RAPID diffractometer equipped with a graphite-monochromated $\mathrm{MoK}_{\alpha}$ radiation
( $\lambda=0.71073 \AA$ ) by using an $\omega$ scan mode at $293(2) \mathrm{K}$ in the range of $1.68^{\circ}=\theta=26^{\circ}$. The crystal belongs to monoclinic system with space group $\mathrm{P} 21 / \mathrm{n}$ and crystal parameters of $\mathrm{a}=6.2705(7), \mathrm{b}=7.9183(8), \mathrm{c}=24.348(2) \AA, \alpha=90, \beta=$ 95.013(2), $\gamma=90^{\circ}, V=1204.3(2) \AA^{3}, D_{c}=1.267 \mathrm{~g} / \mathrm{cm}^{3}$. The absorption coefficient $\mu=0.088 \mathrm{~mm}^{-1}$ and $\mathrm{Z}=2$. Absorption correction was performed by the CRYSTALCLEAR program ${ }^{11}$. The structure was solved by direct methods using the SHELXS-97 program ${ }^{12}$ and refined by full-matrix least-squares techniques on $\mathrm{F}^{2}$ data using SHELXL-97 ${ }^{13}$. The empirical absorption corrections were applied to all intensity data. All the hydrogen atoms were located by using the geometric method, with $\mathrm{d}(\mathrm{C}-\mathrm{H})=0.95-0.98 \AA$ and $\mathrm{Uiso}(\mathrm{H})=1.2 \mathrm{Ueq}(\mathrm{C})$ or $1.5 \mathrm{Ueq}$ (Cmethyl). The final $\mathrm{R}=0.0376$ and $\mathrm{wR}=0.0777$ for 6645 observed reflections with $\mathrm{I}>2 \sigma(\mathrm{I})$ and $\mathrm{R}=0.0542$ and $w R=0.0827$ for all data.

\section{RESULTS AND DISCUSSION}

The 2',3'-dideoxy-6'-fluorocarbocyclic nucleoside 1 could be prepared by two steps from $\alpha$-fluoroalcohol $(\mathbf{2})^{10}$. The Mitsunobu reaction of $\alpha$-fluoroalcohol (2) with 6-chloropurine was chosen for introducing the base to the carbocyclic sugar ring $^{14}$. The coupling of alcohol 2 with 6-chloropurine (2 equiv) in the presence of $\mathrm{PPh}_{3}$ (2.6 equiv) and diethyl azodicarboxylate (2.6 equiv) afforded compound $\mathbf{3}$ with the inversion of $\mathrm{C}(2)$ configuration in the moderate yield of $48 \%$ (Scheme-I). Following by the replacement of 6-chlorine atom by amino group under $\mathrm{NH}_{3} / \mathrm{MeOH}$ condition, the target nucleoside $\mathbf{1}$ was obtained in two successive manipulations in the overall yield of $41 \%$.

Compound 1 was an air-stable white solid and characterized by IR, ${ }^{1} \mathrm{H}$ NMR, ${ }^{13} \mathrm{C}$ NMR, MS spectroscopies. IR spectra of 1 displayed absorptions at $3311 \mathrm{v}(\mathrm{N}-\mathrm{H}), 2922$ $v_{\text {as }}(\mathrm{C}-\mathrm{H}), 2851 v_{\mathrm{s}}(\mathrm{C}-\mathrm{H}), 1647 \mathrm{v}(\mathrm{C}=\mathrm{C}), 1597 v(\mathrm{C}=\mathrm{N}), 1473$ $v\left(\mathrm{C}=\mathrm{N}^{\prime}\right), 1096 \mathrm{v}(\mathrm{C}-\mathrm{O}, \mathrm{C}-\mathrm{N}) \mathrm{cm}^{-1}$. The ${ }^{1} \mathrm{H}$ NMR spectra of compound 1 exhibited a strong spin-spin coupling between $\mathrm{H}(1)$ and $\mathrm{F}(1)$ with the $J^{2}$ coupling constant of $54 \mathrm{~Hz}$. The above coupling of $\mathrm{H}(1)$ and $\mathrm{F}(1)$ was confirmed again in the ${ }^{19} \mathrm{~F}$ NMR. From the analysis of the ${ }^{13} \mathrm{C}$ NMR spectra, the spinspin coupling between $\mathrm{F}(1)$ and $\mathrm{C}(1)$ also be detected in which the coupling constant reached the value of $190.2 \mathrm{~Hz}$.

Subsequently, a white single crystal of 2',3'-dideoxy-6'fluorocarbocyclic nucleoside $\mathbf{1}$ was grown by the slow evaporation of methanol solutions at room temperature and the molecular structure of compound $\mathbf{1}$ was determined by X-ray diffraction analysis. ORTEP and crystal packing diagram of $\mathbf{1}$ are shown in Figs. 1 and 2, respectively and crystallographic and refinement parameters of the title compound $\mathbf{1}$ are listed in Table-1. The selected bond lengths and angles are given in Tables 2 and 3. From ORTEP view of compound 1 (Fig. 1), we could figure out that the Mitsunobu coupling for base

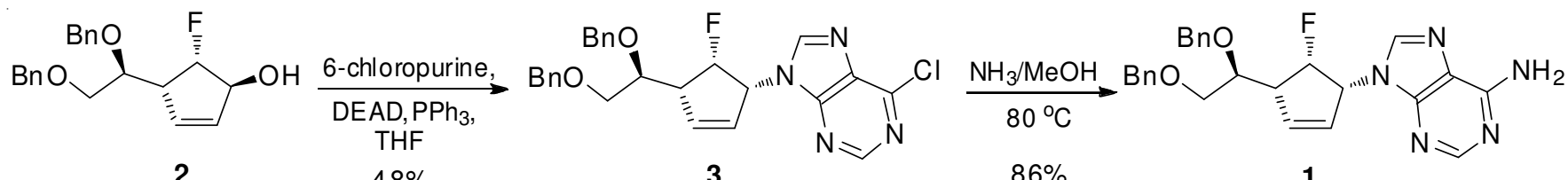

2

$48 \%$

3

$86 \%$

Scheme-I: Preparation of 2',3'-dideoxy-6'-fluorocarbocyclic nucleoside analogue (1) 
introduction takes place selectively at the $\mathrm{C}(2)$ and $\mathrm{N}(1)$ sites with the configuration inversion of $\mathrm{C}(2)$. The bond length of $\mathrm{C}(1)-\mathrm{F}(1)$ is 1.401(3) $\AA$ which is in accordance with the normal C-F bond length (1.39-1.43 $\AA)^{15}$. However, the C(1)-H(1) and $\mathrm{C}(2)-\mathrm{H}(2)$ bond lengths are $0.9800 \AA$ which is far less than the bond length of common $\mathrm{C}^{s{ }^{3}}$-H bonds (1.09-1.10 $\AA$ ). This sharp shortening of bond lengths can be rationally explained by Bent's rule ${ }^{16}$-Atomic $p$-character concentrates in the orbitals directed toward electronegative substituents. As $\mathrm{C}(1)^{s p^{3}}-\mathrm{F}(1)$ and $\mathrm{C}(2)^{s p^{3}}-\mathrm{N}(1)$ pull the $p$-orbital electrons from the $s p^{3}$ carbon to electronegative atoms $(\mathrm{F}$ and $\mathrm{N})$, the bonding orbitals of $\mathrm{C}(1)$ and $\mathrm{C}(2)$ become more s-character and more close to carbon nuclei. As a result, the $\mathrm{C}(1)-\mathrm{H}(1)$ and $\mathrm{C}(2)-\mathrm{H}(2)$ bond lengths shorten significantly in contrast with common $\mathrm{C}^{s p^{3}}-\mathrm{H}$ bonds.

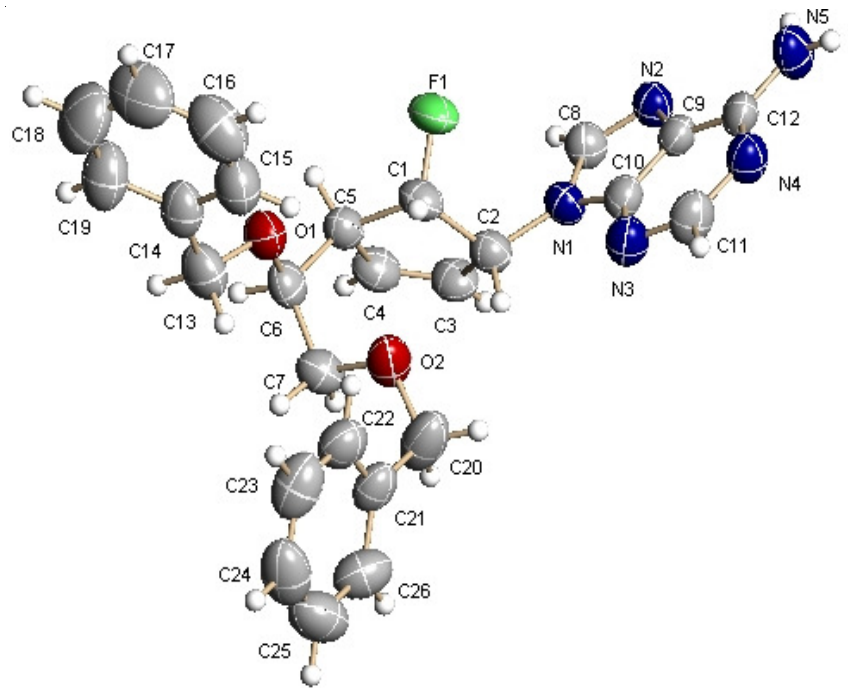

Fig. 1. ORTEP view of compound $\mathbf{1}$ with $30 \%$ probability level ellipsoids

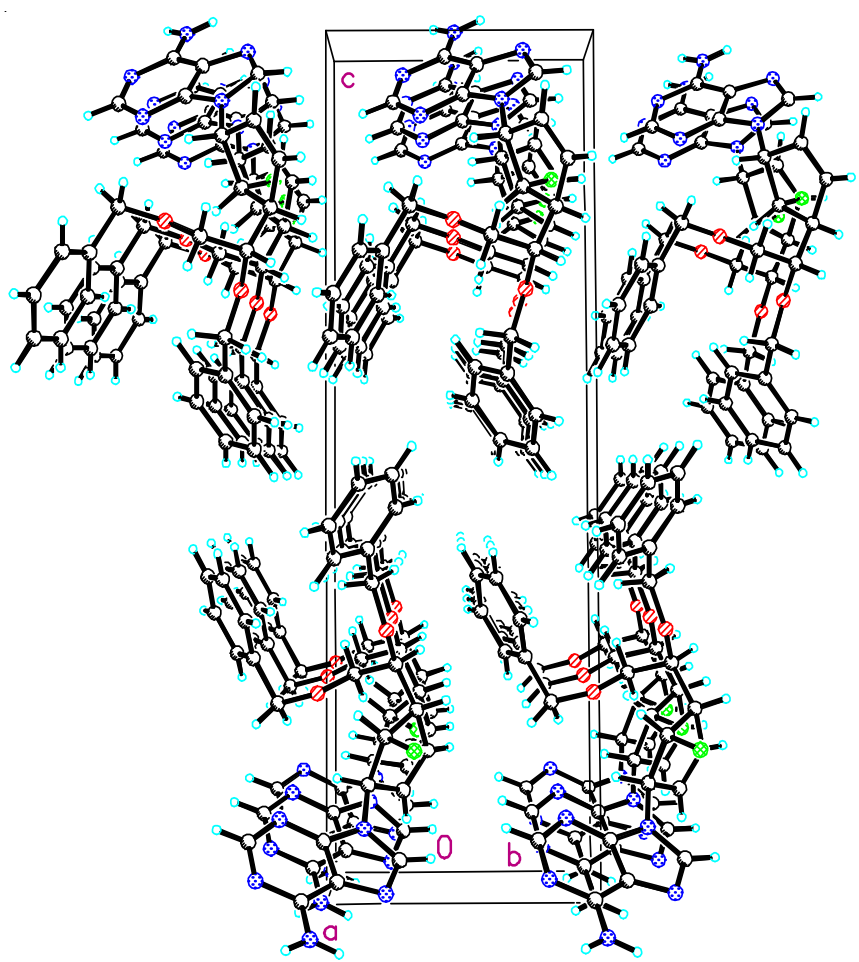

Fig. 2. Crystal packing diagram of compound $\mathbf{1}$

\begin{tabular}{|c|c|}
\hline \multicolumn{2}{|c|}{$\begin{array}{c}\text { TABLE-1 } \\
\text { CRYSTAL DATA AND STRUCTURAL } \\
\text { REFINEMENT FOR COMPOUND } 1\end{array}$} \\
\hline Properties & Data \\
\hline Empirical formula & $\mathrm{C}_{26} \mathrm{H}_{26} \mathrm{~N}_{5} \mathrm{O}_{2} \mathrm{~F}$ \\
\hline Formula weight & 459.52 \\
\hline Crystal system & Monoclinic \\
\hline Unit cell dimensions & \\
\hline $\mathrm{a}(\AA)$ & $6.2705(7)$ \\
\hline$b(\AA)$ & $7.9183(8)$ \\
\hline $\mathrm{c}(\AA)$ & $24.348(2)$ \\
\hline \multicolumn{2}{|l|}{ Unit cell angles $\left({ }^{\circ}\right)$} \\
\hline$\alpha$ & 90.00 \\
\hline$\beta$ & $95.013(2)$ \\
\hline$\gamma$ & 90.00 \\
\hline Volume $\left(\AA^{3}\right)$ & $1204.3(2)$ \\
\hline $\mathrm{Z}$ & 2 \\
\hline Temperature (K) & $293(2)$ \\
\hline Space group & $\mathrm{P} 21 / \mathrm{n}$ \\
\hline Wavelength $(\AA)$ & 0.71073 \\
\hline Calculated density $\left(\mathrm{g} \mathrm{cm}^{-3}\right)$ & 1.267 \\
\hline Absorption coefficient $\mu\left(\mathrm{mm}^{-1}\right)$ & 0.088 \\
\hline $\mathrm{F}(000)$ & 484 \\
\hline Crystal size $\left(\mathrm{mm}^{3}\right)$ & $0.369 \times 0.311 \times 0.079$ \\
\hline$\theta$ range for data collection $\left(^{\circ}\right)$ & $1.68-26.00$ \\
\hline Limiting indices & $\begin{array}{l}-7<=\mathrm{h}<=6,-9<=\mathrm{k}<=9,-26 \\
<=1<=30\end{array}$ \\
\hline Reflection collected & 6645 \\
\hline Independent reflection & $2544\left(\mathrm{R}_{\mathrm{int}}=0.0397\right)$ \\
\hline Completeness to $\theta_{\max }(\%)$ & 99.7 \\
\hline Data/restraints/parameters & $2544 / 1 / 307$ \\
\hline Goodness-of-fit on $\mathrm{F}^{2}$ & 0.891 \\
\hline Final $R$ indices $[I>2 \sigma(I)]$ & $\mathrm{R}_{1}=0.0376, \mathrm{wR}_{2}=0.0777$ \\
\hline $\mathrm{R}$ indices (all data) & $\mathrm{R}_{1}=0.0542, \mathrm{wR}_{2}=0.0827$ \\
\hline Largest diff. peak and hole $\left(\mathrm{eA}^{-3}\right)$ & 0.134 and -0.112 \\
\hline
\end{tabular}

\begin{tabular}{|c|c|}
\hline \multicolumn{2}{|c|}{$\begin{array}{c}\text { TABLE-2 } \\
\text { SELECTED BOND LENGTHS (§̊) FOR COMPOUND }\end{array}$} \\
\hline Bond & Bond length $(\AA)$ \\
\hline $\mathrm{F}(1)-\mathrm{C}(1)$ & $1.401(3)$ \\
\hline $\mathrm{N}(1)-\mathrm{C}(2)$ & $1.451(3)$ \\
\hline$C(5)-C(6)$ & $1.523(3)$ \\
\hline $\mathrm{C}(1)-\mathrm{H}(1)$ & 0.9800 \\
\hline $\mathrm{C}(2)-\mathrm{H}(2)$ & 0.9800 \\
\hline $\mathrm{C}(1)-\mathrm{C}(2)$ & $1.545(3)$ \\
\hline$C(1)-C(5)$ & $1.530(3)$ \\
\hline $\mathrm{C}(2)-\mathrm{C}(3)$ & $1.485(4)$ \\
\hline$C(4)-C(5)$ & $1.500(4)$ \\
\hline $\mathrm{C}(3)=\mathrm{C}(4)$ & $1.304(3)$ \\
\hline $\mathrm{C}(7)-\mathrm{H}(7 \mathrm{~A})$ & 0.9700 \\
\hline $\mathrm{C}(7)-\mathrm{H}(7 \mathrm{~B})$ & 0.9700 \\
\hline $\mathrm{C}(3)-\mathrm{H}(3)$ & 0.9300 \\
\hline $\mathrm{N}(5)-\mathrm{H}(5 \mathrm{~A})$ & 0.8600 \\
\hline $\mathrm{N}(5)-\mathrm{H}(5 \mathrm{~B})$ & 0.8600 \\
\hline
\end{tabular}

With the preliminary view of molecular architecture in hand, we then turn our attention to analyze the intermolecular interactions in this nucleoside analogue crystal. It is well known that the hydrogen-bonding properties of the organic compounds directly correlate to molecular recognition and pharmacological activities ${ }^{17}$. In the crystal structure of nucleoside analogue 1, the hydrogen-bonds $\mathrm{N}(5)-\mathrm{H}(5 \mathrm{~B}) \cdots \mathrm{N}(4) \# 1$ and $\mathrm{N}(5)-\mathrm{H}(5 \mathrm{~A}) \cdots \mathrm{N}(2) \# 2$ are formed in networks which make 


\begin{tabular}{cc}
\hline \multicolumn{2}{c}{ TABLE-3 } \\
SELECTED BOND ANGLES $\left(^{\circ}\right)$ FOR COMPOUND 1 \\
\hline Bond & Bond angles $\left(^{\circ}\right)$ \\
\hline $\mathrm{F}(1)-\mathrm{C}(1)-\mathrm{H}(1)$ & 111.8 \\
$\mathrm{~F}(1)-\mathrm{C}(1)-\mathrm{C}(5)$ & $107.3(2)$ \\
$\mathrm{F}(1)-\mathrm{C}(1)-\mathrm{C}(2)$ & $107.88(19)$ \\
$\mathrm{N}(1)-\mathrm{C}(2)-\mathrm{H}(2)$ & 108.6 \\
$\mathrm{C}(6)-\mathrm{C}(5)-\mathrm{H}(5)$ & 108.0 \\
$\mathrm{C}(5)-\mathrm{C}(1)-\mathrm{C}(2)$ & $105.8(2)$ \\
$\mathrm{C}(3)-\mathrm{C}(2)-\mathrm{C}(1)$ & $102.7(2)$ \\
$\mathrm{C}(4)-\mathrm{C}(5)-\mathrm{C}(1)$ & $102.5(2)$ \\
$\mathrm{C}(3)-\mathrm{C}(4)-\mathrm{C}(5)$ & $112.8(2)$ \\
$\mathrm{C}(4)-\mathrm{C}(3)-\mathrm{C}(2)$ & $112.4(2)$ \\
$\mathrm{O}(2)-\mathrm{C}(7)-\mathrm{C}(6)$ & $108.7(2)$ \\
$\mathrm{H}(7 \mathrm{~A})-\mathrm{C}(7)-\mathrm{H}(7 \mathrm{~B})$ & 108.3 \\
$\mathrm{H}(5 \mathrm{~A})-\mathrm{N}(5)-\mathrm{H}(5 \mathrm{~B})$ & 120.0 \\
$\mathrm{C}(4)-\mathrm{C}(3)-\mathrm{H}(3)$ & 123.8 \\
$\mathrm{C}(3)-\mathrm{C}(4)-\mathrm{H}(4)$ & 123.6 \\
\hline
\end{tabular}

important contributions to the topologic structure (Figs. 3 and 4). The bond length values and geometries of these hydrogenbonds are summarized in Table-4. Both the short distance of $\mathrm{d}(\mathrm{D} \cdots \mathrm{A})$ and nearly collinear arrangement of D-H...A indicate that $\mathrm{N}(5)-\mathrm{H}(5 \mathrm{~B}) \cdots \mathrm{N}(4) \# 1$ and $\mathrm{N}(5)-\mathrm{H}(5 \mathrm{~A}) \cdots \mathrm{N}(2) \# 2$ are genuine moderate hydrogen-bonds (Table-2). Additionally, it is interesting to find out that $\mathrm{C}(1)-\mathrm{F}(1) \cdots \mathrm{H}(7 \mathrm{~B})-\mathrm{C}(7)^{s p^{3}}$ contacted in a distance of $2.655 \AA$ which is within the sum of van der Waals radii of hydrogen and fluorine (2.670 ̊) (Fig. 5). In view of the slightly shortening effect of contact distance versus van der Waals radii, $\mathrm{C}(1)-\mathrm{F}(1) \cdots \mathrm{H}(7 \mathrm{~B})-\mathrm{C}(7)^{s p^{3}}$ can be considered as a "weak" hydrogen bond rather than a "genuine" hydrogen bond ${ }^{18}$ which arises from the electrostatic attraction of positive charge on $\mathrm{H}(7 \mathrm{~B})$ and negative charge on $\mathrm{F}(1)$ like the reported C-F...H- $\mathrm{C}_{\alpha}\left(\mathrm{C}_{\alpha}\right.$ carbon of carbonyl compounds or amino acids)

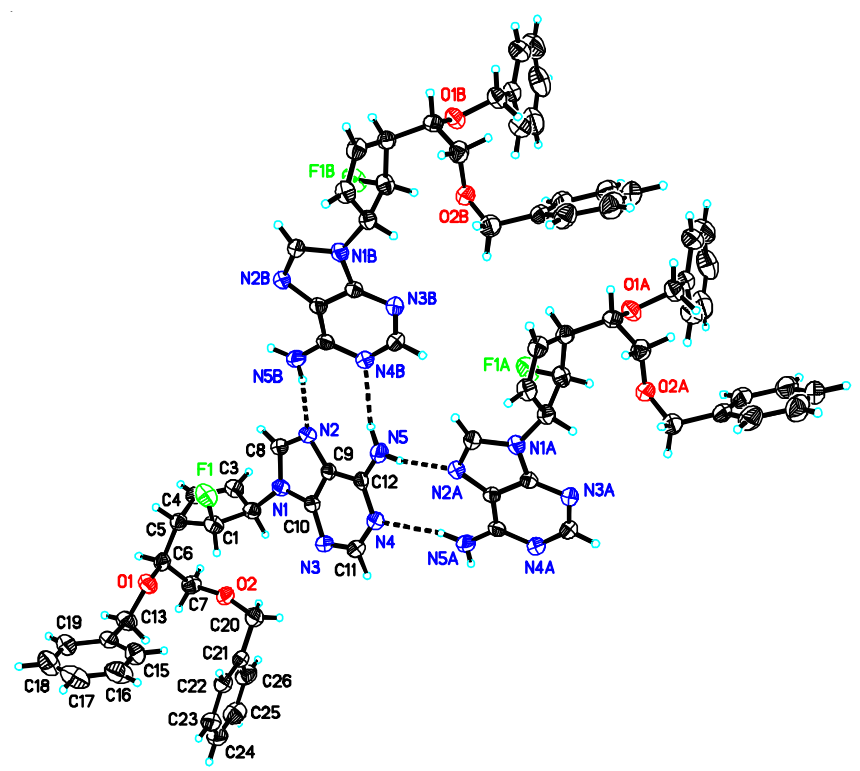

Fig. 3. Hydrogen-bonds in the single crystal for compound $\mathbf{1}$

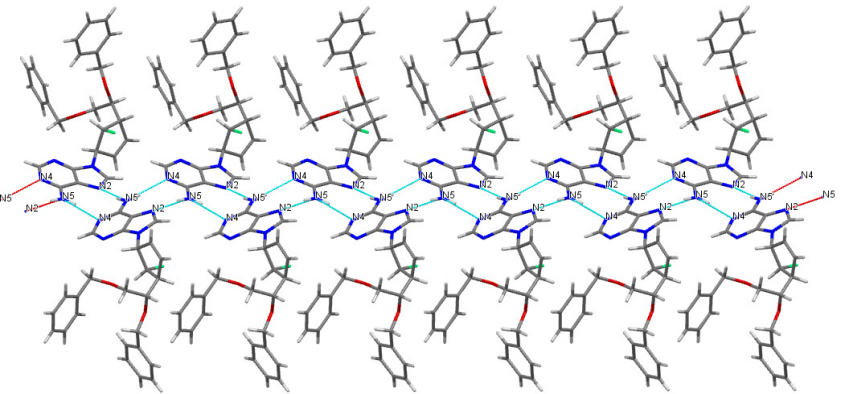

Fig. 4. Hydrogen-bonding networks in crystal $\mathbf{1}$

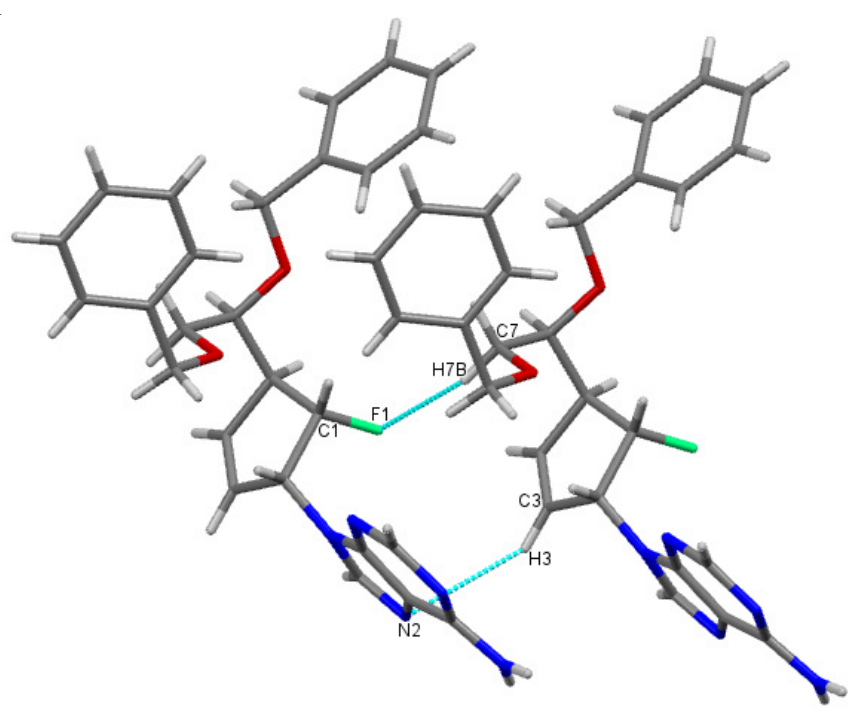

Fig. 5. Electrostatic interactions of $\mathrm{C}(1)-\mathrm{F}(1) \cdots \mathrm{H}(7 \mathrm{~B})-\mathrm{C}(7)^{s p^{3}}$ and $\mathrm{N}(2) \cdots \mathrm{H}(3)-\mathrm{C}(3)^{s p^{2}}$

interactions in Cambridge Structural Database (CSD) $)^{19-20}$. Moreover, the short contact also exists in $\mathrm{N}(2) \cdots \mathrm{H}(3)-\mathrm{C}(3)^{s p^{2}}$ with the length of $2.726 \AA$ which also stem from the electrostatic attraction between the positive charge on $\mathrm{H}(3)$ and negative charge on $\mathrm{N}(2)$ (Fig. 5). It is evident that this $\mathrm{N}(2) \cdots \mathrm{H}(3)-\mathrm{C}(3)^{s p^{2}}$ contact is significantly distinguished from the conventional $\mathrm{N} \cdots \mathrm{H}-\mathrm{X}$ hydrogen-bonds ${ }^{20}$.

\section{Conclusion}

In conclusion, we described herein the synthesis, characterization and X-ray crystal structure of 2',3'-dideoxy-6'fluorocarbocyclic nucleoside analogue 1 . The X-ray crystal structure shows that the hydrogen-bonds $\mathrm{N}(5)-\mathrm{H}(5 \mathrm{~B}) \cdots \mathrm{N}(4) \# 1$ and $\mathrm{N}(5)-\mathrm{H}(5 \mathrm{~A}) \cdots \mathrm{N}(2) \# 2$ are important binding forces for the topologic structure. Two uncommon "weak" hydrogen-bonds $\mathrm{C}(1)-\mathrm{F}(1) \cdots \mathrm{H}(7 \mathrm{~B})-\mathrm{C}(7)^{s p^{3}}$ and $\mathrm{N}(2) \cdots \mathrm{H}(3)-\mathrm{C}(3)^{s p^{2}}$ are also unveiled which could be interpreted as the electrostatic attraction. Further investigations of the relationship between the structural characteristics of nucleoside analogue $\mathbf{1}$ and its bioactivity are underway and the results will be reported in due course.

\begin{tabular}{ccccc}
\multicolumn{7}{c}{ TABLE-4 } \\
BOND LENGTHS AND GEOMETRIES OF HYDROGEN-BONDS FOR COMPOUND 1 \\
\hline $\mathrm{D}-\mathrm{H} \cdots \mathrm{A}$ & $\mathrm{d}(\mathrm{D}-\mathrm{H})(\AA)$ & $\mathrm{d}(\mathrm{H} \cdots \mathrm{A})(\AA)$ & $\mathrm{d}(\mathrm{D} \cdots \mathrm{A})(\AA)$ & $\angle \mathrm{A})$ \\
\hline $\mathrm{N}(5)-\mathrm{H}(5 \mathrm{~B}) \cdots \mathrm{N}(4) \# 1$ & 0.86 & 2.18 & $3.003(3)$ & $158.9^{\circ}$ \\
$\mathrm{N}(5)-\mathrm{H}(5 \mathrm{~A}) \cdots \mathrm{N}(2) \# 2$ & 0.86 & 2.17 & $3.025(3)$ & $170.5^{\circ}$ \\
\hline
\end{tabular}


Supplementary data L: CCDC-805686 contains the supplementary crystallographic data for this paper. These data can be obtained free of charge via http://www.ccdc.cam.ac.uk/ conts/retrieving.html, or from the Cambridge Crystallographic Data Centre, 12 Union Road Cambridge CB2 1EZ, UK (Fax: +44-1223-336033; or E-mail: deposit@ccdc.cam.ac.uk).

\section{ACKNOWLEDGEMENTS}

Sichuan University of Science \& Engineering (2012RC17, 2012RC15, 2011RC06), Zigong Science and Technology Bureau (2013X02), Education Department of Sichuan Province (14ZB0207) and Key Laboratory of Green Chemistry of Sichuan Institutes of Higher Education (LZJ1401) are greatly acknowledged for funding this work.

\section{REFERENCES}

1. S. Purser, P.R. Moore, S. Swallow and V. Gouverneur, Chem. Soc. Rev., 37, 320 (2008)

2. K.L. Kirk, Org. Process Res. Dev., 12, 305 (2008).

3. J. Wang and H. Liu, Chin. J. Org. Chem., 31, 1785 (2011).

4. J.P. Bégué and D. Bonnet-Delpon, J. Fluor. Chem., 127, 992 (2006).
5. C. Isanbor and D. O'Hagan, J. Fluor. Chem., 127, 303 (2006).

6. K.L. Kirk, J. Fluor. Chem., 127, 1013 (2006)

7. F.M.D. Ismail, J. Fluor. Chem., 118, 27 (2002).

8. K. Müller, C. Faeh and F. Diederich, Science, 317, 1881 (2007).

9. F. Zheng, L. Fu, R. Wang and F.L. Qing, Org. Biomol. Chem., 8, 163 (2010).

10. Y. Yang, F. Zheng and F.L. Qing, Tetrahedron, 67, 3388 (2011).

11. Crystal Clear and Crystal Structure, Rigaku and Rigaku Americas. 9009 New Trails Dr. The Woodlands TX 77381 USA.

12. G.M. Sheldrick, SHELXS97, A Program for Crystal Structure Solution, University of Göttingen: Germany (1997).

13. G.M. Sheldrick, SHELXS97, A Program for Crystal Structure Refinement, University of Göttingen: Germany (1997).

14. K.C.K. Swamy, N.N.B. Kumar, E. Balaraman and K.V.P.P. Kumar, Chem. Rev., 109, 2551 (2009).

15. D. O'Hagan, Chem. Soc. Rev., 37, 308 (2008).

16. H.A. Bent, Chem. Rev., 61, 275 (1961).

17. C. Bissantz, B. Kuhn and M. Stahl, J. Med. Chem., 53, 5061 (2010).

18. K. Uneyama, Organofluorine chemistry, Blackwell Publishing Ltd., Oxford (2006).

19. R. Paulini, K. Müller and F. Diederich, Angew. Chem. Int. Ed., 44, 1788 (2005).

20. J.A. Olsen, D.W. Banner, P. Seiler, B. Wagner, T. Tschopp, U. Obst-Sander, M. Kansy, K. Müller and F. Diederich, ChemBioChem, 5, 666 (2004). 